\title{
"Day-of-the-week effect in Nigerian stock exchange: adaptive market hypothesis
}

approach"

\begin{tabular}{|c|c|}
\hline AUTHORS & $\begin{array}{l}\text { Anthony Olugbenga Adaramola (D https://orcid.org/0000-0001-9572-4092 } \\
\text { Kehinde Oladeji Adekanmbi }\end{array}$ \\
\hline ARTICLE INFO & $\begin{array}{l}\text { Anthony Olugbenga Adaramola and Kehinde Oladeji Adekanmbi (2020). Day-of- } \\
\text { the-week effect in Nigerian stock exchange: adaptive market hypothesis } \\
\text { approach. Investment Management and Financial Innovations, 17(1), 97-108. } \\
\text { doi:10.21511/imfi.17(1).2020.09 }\end{array}$ \\
\hline DOI & http://dx.doi.org/10.21511/imfi.17(1).2020.09 \\
\hline RELEASED ON & Monday, 02 March 2020 \\
\hline RECEIVED ON & Thursday, 21 November 2019 \\
\hline ACCEPTED ON & Wednesday, 18 December 2019 \\
\hline LICENSE & $\begin{array}{l}(c)) \text { EY } \\
\text { This work is licensed under a Creative Commons Attribution } 4.0 \text { International } \\
\text { License }\end{array}$ \\
\hline JOURNAL & "Investment Management and Financial Innovations" \\
\hline ISSN PRINT & $1810-4967$ \\
\hline ISSN ONLINE & $1812-9358$ \\
\hline PUBLISHER & LLC "Consulting Publishing Company "Business Perspectives" \\
\hline FOUNDER & LLC "Consulting Publishing Company "Business Perspectives" \\
\hline
\end{tabular}

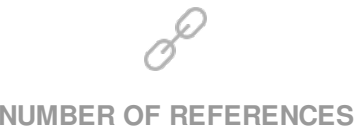

25
NUMBER OF FIGURES

1
ニニ:

NUMBER OF TABLES

3

(C) The author(s) 2022. This publication is an open access article. 


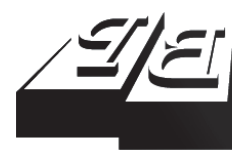

\section{BUSINESS PERSPECTIVES}

LLC "CPC "Business Perspectives" Hryhorii Skovoroda lane, 10, Sumy, 40022, Ukraine www.businessperspectives.org
Received on: $21^{\text {st }}$ of November, 2019 Accepted on: $18^{\text {th }}$ of December, 2019 Published on: $2^{\text {nd }}$ of March, 2020

() Anthony Olugbenga Adaramola, Kehinde Oladeji Adekanmbi, 2020

Anthony Olugbenga Adaramola, Ph.D., Associate Professor, Department of Finance, Faculty of Management Sciences, Ekiti State University, Nigeria.

Kehinde Oladeji Adekanmbi, Ph.D. Student, Department of Finance, Faculty of Management Sciences, Ekiti State University, Nigeria.
This is an Open Access article, distributed under the terms of the Creative Commons Attribution 4.0 International license, which permits unrestricted re-use, distribution, and reproduction in any medium, provided the original work is properly cited.

Conflict of interest statement: Author(s) reported no conflict of interest

Anthony Olugbenga Adaramola (Nigeria), Kehinde Oladeji Adekanmbi (Nigeria)

DAY-OF-THE-WEEK EFFECT

IN NIGERIAN STOCK

EXCHANGE: ADAPTIVE MARKET HYPOTHESIS APPROACH

\begin{abstract}
The problems that this study informed are rooted in the uncertainty surrounding the presence of calendar anomalies in the Nigerian stock market and the need to ascertain whether calendar anomaly is changing with time and market condition according to the adaptive market hypothesis. This study evaluates how calendar anomaly behaves over time in the Nigerian stock market through the day-of-the-week effect since the latest trend is to examine time-changing anomaly. The general All Share Index returns of the Nigerian Stock Exchange between 2000 and 2017 are used in the analysis. Secondary daily index returns data for the period are sourced from the NSE Fact Book. The major estimation techniques employed in the study are the mean equations of the generalized autoregressive conditional heteroscedasticity $(\mathrm{GARCH})$ and overlapping sub-period methodology. Moreover, returns are grouped into Up and Down periods depending on the periods that generate positive and negative returns, respectively. This study found out that Monday (MON), Tuesday (TUE), and Friday (FRI) effects are the only adaptive day-of-the-week effects. Thus, three (MON, TUE, FRI) day of the week effects found in the full sample are time-varying in subsample and are affected by market condition. On the whole, MON and Thursday (THUR) effects are found in Bull, while TUE and FRI are found in Bear.The investor must be careful to take timevariation into consideration; otherwise, they may incur a loss by thinking that the dayof-the-week effect is present every time.
\end{abstract}

Keywords

JEL Classification

\section{INTRODUCTION}

The presence of calendar anomalies has been documented extensively for the last four decades in financial markets. However, the subject is yet to receive adequate attention from developing markets such as Nigerian stock markets. Submissions from most studies of weak and semi strong form hypotheses imply that the Nigerian stock market, like many other emerging markets, is not efficient. The implication of this is that stock return anomalies could be present in the market so that investors can consistently earn abnormal returns by targeting certain periods for trading or using a trading strategy based on past information. In the presence of this inefficiency, the activities of sharp speculators are prevalent, and speculation is done at the expense of uninformed investors, which is not good for the nation's financial market. Among anomalies, calendar anomaly is prominent. Osarumwense (2015) examined the day-of-the-week calendar effect, while Efayena (2014) and Olowe (2011) investigated the month-of-theyear calendar effect in Nigeria with the latter focusing on oil price returns as opposed to stock price returns.

More so, the advent of adaptive market hypothesis (AMH) has caused a revision of calendar anomalies in recent literature. Furthermore, the 
$\mathrm{AMH}$ argues that market efficiency is not stable but has time-varying feature, and this has a strong implication for the study of calendar effects. The theory states that efficiency changes over time (Lo, 2004), and researchers are now curious to ascertain whether anomalies change over time. The authors are still at a period of further research into the capital market theories, notably the AMH. As markets continue to witness further developments and discoveries, many empirical works are being carried out, and the results in the most cases are not in tune with the efficient market hypothesis (EMH). This study, therefore, aims at untangling the day-of-the-week calendar anomaly within the Nigerian stock market in order to establish whether this calendar effect is consistent with AMH.

\section{LITERATURE REVIEW}

Akkaya and Çimen (2013), Güler and Çimen (2014) opined that financial anomaly is synonymous with abnormal return, which implies a deviation from the average return. An anomaly is defined as a price or profit distortion, which is evidence of inefficiency within the financial markets (Kroon, 2008). It is usually a result of structural factors such as unfair competition, lack of transparency in the market or behavioral biases by various economic agents, which forms the bedrock of behavioral finance. It is used to describe a situation where changes in stock returns display high or low patterns at certain calendar periods (Yousop, Sipon, \& Yoke, 2014). Applying descriptive analysis, decomposition method, dummy variable regression and binary logistic regression, Gulseven (2014) used stock market indices spanning from 1996 to 2014 to check for the monthly market anomalies in Turkish and American Stock Exchanges. The study revealed a strikingly negative May effect on the Turkish stocks and a positive return in April. Stocks tend to be bullish in December in both markets, and there is no significant January effect.

Patel (2016) evaluated the January effect anomaly in stock returns using U.S. stock, Russell developed stock, Russell Asia-Pacific stock, Russell Europe stock, Russell Latin-America stock and the Russell Emerging stock indices from 1997 to 2014. OLS dummy regression and descriptive statistics analyses revealed that January effect in stock returns does not exist as January returns are negative and statistically insignificant, while December returns are positive and statistically significant. Kampman (2012) examined January anomalies in US using daily index for a period between 1975 and 2000. Results of descriptive statistics and dummy regression revealed that the presence of the
January effect is not significant at 0.05 probability level. Tevdovski, Mihajlov, and Sazdovski (2012) examined the day-of-the-week effect of stock returns in South Eastern Europe, namely Bosnia and Herzegovina, Bulgaria, Croatia, Macedonia, and Serbia between 2006 and 2011. Results of dummy regression, analysis of variance, and Wald test revealed that the mean daily return of all stock indices is negative on Monday in all markets; lesser and significant on Monday than the other days of the week in Croatia and Bulgaria but insignificant in Macedonia, while the same are lower in Tuesday than mean daily return on Monday but statistically insignificant in BELEX 15 and BIFX.

Using All Share Index of Nigeria, Kenya, Tunisia, Morocco, South Africa, Egypt, and Zimbabwe, Alagidede (2013) evaluated the implication of month of the year and the pre-holiday effects for efficiency in African stock market. The descriptive statistics of the mean and variance of returns and dummy regression found high and significant returns in days preceding a holiday in South Africa; a February effect for Morocco, Kenya, Nigeria, and South Africa; a January effect in Egypt and Zimbabwe and monthly seasonality is pronounced for Nigeria. GARCH model employed due to the presence of conditional heteroscedasticity showed that Zimbabwe exhibits more significant negative returns virtually throughout the year with only September and April showing significant negative returns in Nigeria. Overall, results indicate that the month-of-the-year effect is prevalent in African stock returns. Osarumwense (2016) concluded that the day-of-the-week anomalies in foreign exchange market lies on the choice of model specified. Ajao and Wemambu (2012) examined the volatility and prediction of Nigerian stock market using monthly data from 2005 to 2009. Result of autoregressive conditional heteroscedasticity (ARCH) showed the presence of vola- 
tility and that stock market prices may indeed be predicted.

In addition, Tan and Tat (1998) show that the January effect and daily effects, among others, are diminishing in Singapore using two sub-periods, while WingKeung, Aman, and NeeTat (2006) revealed that calendar effects are weakening across the sub-periods. New growing trend in literature is the changing behavior of calendar anomalies in reaction to different market conditions (i.e., Bull and Bear markets, and market crashes). Such proof, according to Urquhart and McGroarty (2014), would be in line with AMH as opposed to the EMH. Urquhart and McGroarty (2014) found that calendar anomalies perform in an adaptive style by estimating them in six subsamples and overlapping windows. The review also disclosed that, apart from the stock market, seasonal effect has also been investigated for other commodity markets, such as the oil market and foreign exchange market. For instance, Olowe (2011) and Osarumwense (2016) in Nigeria studied the month-of-the-year and day-of-the-week, respectively, in oil market and foreign exchange market. That is to say, some of the calendar anomalies have been investigated in Nigeria. However, calendar anomaly has not been investigated in line with the AMH in Nigeria. To the best of our knowledge, there seems to be scarcity of study investigating whether calendar anomalies change over time in Nigerian stock market.

\section{RESEARCH METHODS}

\subsection{Source and description of data}

The study employs secondary data. The Nigerian Stock Exchange (NSE) daily index was obtained from the Capital Asset Section of NSE Fact Book available online. Daily return data are calculated from the index for eighteen years (2000-2017) during which the data are available. Daily return is obtained based on the formula in equation (1):

$$
R_{t}=\log \left(\frac{P_{t}}{P_{t-1}}\right),
$$

where $P_{t}$ and $P_{t-1}$ indicate stock indices on day $t$ and $t-1$, respectively, and $R_{t}$ is the stock return on day $t$ say Monday price relative to Friday price.

\subsection{Model specification}

The main objective of this study is to establish various calendar effects in mean returns, ranging from the weekdays effect and monthly/January effect. Borges (2009) presents a critique of various models used in the estimation of calendar effect. A familiar approach of modelling the calendar effect on stock market indexes is by estimating the subsequent equation. In case the day-of-the-week effect, Borges (2009) notes that the five days from Monday through Tuesday are usually coded 1, 2, 3, 4, 5, respectively. Thus:

$$
\begin{aligned}
& r_{t}=\alpha+\beta_{2} D_{2 t}+\beta_{3} D_{3 t}+ \\
& +\beta_{4} D_{4 t}+\beta_{5} D_{5 t}+\varepsilon_{t}, \\
& r_{t}=\beta_{1} D_{1 t}+\beta_{2} D_{2 t}+\beta_{3} D_{3 t}+ \\
& +\beta_{4} D_{4 t}+\beta_{5} D_{5 t}+\varepsilon_{t},
\end{aligned}
$$

where $t$ is the daily return of index on day $t, D_{i t}$ are the dummy variable, which is equal to 1 if the corresponding return for day $t$ is Tuesday, Wednesday, Thursday, and Friday, respectively and 0 if not. $i=2,3,4,5$ and $\varepsilon_{t}$ is the error term. The first equation (2) or specification can only reveal through $\beta_{2}$ whether Tuesday returns differ significantly from Monday's but cannot compare Tuesday with other days. In equation (3), if the sample size is considerably long, mean daily return tends to be positive. Consequently, the $t$-tests are biased towards accepting positive excess returns, and against accepting negative excess returns (Borges, 2009). Borges (2009) argues that the alternative to the above equations is to adopt a simpler approach, which surmounts all these limitations, which is to estimate five equations separately, each with to spot a particular day-of-the-week effect:

$$
r_{t}=\alpha+\beta_{i} D_{i t}+\varepsilon_{t}
$$

Based on equation (4), if dummy variable is included for Mondays alone, $\alpha$ accounts for the mean daily return of remaining four days, and $\beta_{1}$ is the excess return of Mondays, in comparison to remaining days. The $t$-test of $\beta$ reveals whether Monday effect is significant, and the same arguments hold for $\beta_{2}, \beta_{3}, \beta_{4}$ and $\beta_{5}$, for detecting other day-of-the-week effects. Thus equation (4) is adopted in this study as recent studies such as Urquhart and McGroarty (2014) have embraced it. 
For weekend effect to exist, $\beta_{1}$ must be low or negative and $\beta_{5}$ must be high and positive and statistically significant.

\subsection{Overlapping sub-period analysis}

To evaluate how calendar anomalies, vary (behave) over time in the Nigerian stock market, the study will employ overlapping sub-period analyses in the estimation of specified calendar anomaly equations (4). This is also known as rolling window analysis, which is used by scholars (Urquhart \& McGroarty, 2014; Obalade \& Muzindutsi, 2018) in the investigation of $\mathrm{AMH}$. Attention is paid to the behavior of the coefficient of calendar effect of interest between positive and negative coefficient and between statistical significance and insignificance of the coefficient. If the behavior changes over time as the rolling sub-period changes, then, it will be concluded that the behavior of calendar anomaly is consistent with AMH. This study adopts 4-year overlapping sub-period, moved one year forward to account for the changes in behavior of calendar anomalies over time.

\subsection{Estimation techniques}

The Generalized Autoregressive Conditional Heteroscedasticity (GARCH) estimation technique is used to estimate the equation (4). GARCH $(1,1)$ is the best model in the estimation of calendar anomalies (Urquhart \& McGroarty, 2014). The simplest GARCH $(1,1)$ specification is presented as follows:

$$
\begin{aligned}
& Y_{t}=X_{t}^{\prime} \phi+\varepsilon_{t}, \\
& \delta_{t}^{2}=w+\pi_{1} \varepsilon_{t-1}^{2}+\lambda_{1} \delta_{t-1}^{2} .
\end{aligned}
$$

Equation (5) represents the mean equation, while equation (6) represents the variance equation. The former is given as a function of exogenous variables and stochastic error term, while the latter depends on three components, namely the constant term $(w)$, the squared residual in the preceding period $\left(\varepsilon_{t-1}^{2}\right)$ and the forecast variance in the preceding period $\left(\delta_{t-1}^{2}\right)$. The $(1,1)$ in $\operatorname{GARCH}(1,1)$ implies that both the autoregressive GARCH term and moving average ARCH term are taken at order one (1). According to Brook (2014), a GARCH $(1,1)$ model can handle stock return characteris- tics and is the commonest in the academic finance literature.

\section{RESULTS AND INTERPRETATIONS}

In this section, results are presented in the order of the objectives. In other words, the first subsection of this section accommodates the results of test of calendar anomalies in mean returns in absolute form. Further, the results of time-changing calendar anomalies are presented and, lastly, the results of calendar anomalies under Up (Bull) and Down (Bear) conditions are presented. The section is concluded by the discussion of findings with reference to exiting studies and theory, while implications of findings are highlighted for the stakeholders.

\subsection{Calendar anomalies (full sample)}

This study ran calendar effect model for each dayof-the-week against all other days. Hence the coefficient of a particular day, say, MON, reflects the excess or deficit of MON compared to (C), which is the mean daily return of non-Monday days, etc. The full sample results of the five equations for each day-of-the-week effect is summarized in Table 1. It can be seen that the popular negative Monday effect is present with the day having negative return. The $t$-test of the coefficient shows that the negative MON effect is significant since the probability value is less than $5 \%$ significance level. Similarly, the results of the TUE model reveal that there is negative TUE effect evidenced by negative value of TUE coefficient, relative to other days. Conversely, the coefficients of returns associated with the WED and THUR are positive and higher relative to the average returns on other days. However, WED and THUR effect cannot be said to exist since the $t$-statistic tests of the relevant coefficients are not statistically significant. From the results of FRI effect model, the FRI coefficient is positive and higher than other days average returns. It means that the FRI effect is positive since the $t$-statistics is equally statistically significant.

Based on the examination of the day-of-the-week effect in absolute form, it can be seen that there is negative MON and TUE effects, as well as the 
Table 1. Day-of-the-week effect results

\begin{tabular}{|c|c|c|c|c|c|c|c|c|c|}
\hline Sample & Variable & Coefficient & Std. Error & Z-statistic & Prob. & Q-stat & Prob. & ARCH & Prob. \\
\hline \multirow{2}{*}{ FULL } & C & $0.030371^{* * *}$ & 0.011508 & 2.639184 & 0.0083 & 1.8776 & 0.171 & 0.166695 & 0.6831 \\
\hline & MON & $-0.073334 * * *$ & 0.025996 & -2.820955 & 0.0048 & - & - & - & - \\
\hline \multirow{2}{*}{ FULL } & C & $0.027417^{* * *}$ & 0.011675 & 2.348421 & 0.0189 & 2.0857 & 0.149 & 0.174968 & 0.6758 \\
\hline & TUE & $-0.058003^{* * *}$ & 0.024732 & -2.345272 & 0.0190 & - & - & - & - \\
\hline \multirow{2}{*}{ FULL } & C & 0.012023 & 0.011530 & 1.042742 & 0.2971 & 2.0827 & 0.149 & 0.171145 & 0.6791 \\
\hline & WED & 0.020034 & 0.025494 & 0.785847 & 0.4320 & - & - & - & - \\
\hline \multirow{2}{*}{ FULL } & C & 0.007935 & 0.011695 & 0.678470 & 0.4975 & 1.9360 & 0.164 & 0.186514 & 0.6659 \\
\hline & THUR & 0.040294 & 0.025148 & 1.602300 & 0.1091 & - & - & - & - \\
\hline \multirow{2}{*}{ FULL } & C & $0.002324 * * *$ & 0.011596 & 0.200412 & 0.8412 & 2.3008 & 0.129 & 0.138483 & 0.7098 \\
\hline & FRI & $0.069869^{* * *}$ & 0.025879 & 2.699825 & 0.0069 & - & - & - & - \\
\hline
\end{tabular}

Note: significance of estimated coefficients is taken at $p$-value (Prob.) $<1 \%$ or $5 \%,(* * * \& * *)$.

positive FRI effect in the Nigerian stock market. These effects translate to what is theoretically referred to as the weekend effect characterized by positive and significantly high FRI returns and negative and significantly low MON returns.

\subsection{Time-varying behavior of calendar anomalies}

The examination of calendar anomalies in stock returns in absolute form as done in subsection 3, has been challenged with the emergence of AMH in recent times. AMH suggests that the best way to follow is to anomalies over time. Consequently, the results of the calendar anomalies based on overlapping sub-period analyses are discussed in this subsection.

The results of overlapping sub-period estimations for all days of the week are presented in Table 2 . Overall, there are fifteen sub-period windows. Again, mean returns are lower or negative on Mondays. However, only five sub-periods (20032006, 2008-2011, 2009-2012, and 2010-2013) demonstrate statistically significant negative MON effect with the $t$-statistic difference being significant at $1 \%$. Therefore, the negative MON effect varies between significant and insignificant

Table 2. Results of time-varying day-of-the-week effect

\begin{tabular}{|c|c|c|c|c|c|}
\hline Sample period & Variables & Coefficient & Std. error & Z-statistic & Prob. \\
\hline \multirow{2}{*}{ 2000-2003 } & C & $0.063956^{* * *}$ & 0.023310 & 2.743685 & 0.0061 \\
\hline & MON & -0.012879 & 0.048827 & -0.263758 & 0.7920 \\
\hline \multirow{2}{*}{ 2001-2004 } & C & $0.056524 * *$ & 0.026547 & 2.129170 & 0.0332 \\
\hline & MON & -0.054841 & 0.057358 & -0.956122 & 0.3390 \\
\hline \multirow{2}{*}{ 2002-2005 } & $C$ & $0.048635^{*}$ & 0.027145 & 1.791707 & 0.0732 \\
\hline & MON & -0.097333 & 0.060186 & -1.617212 & 0.1058 \\
\hline \multirow{2}{*}{ 2003-2006 } & $C$ & $0.051447 * *$ & 0.025011 & 2.057023 & 0.0397 \\
\hline & MON & $-0.108001^{*}$ & 0.059150 & -1.825895 & 0.0679 \\
\hline \multirow{2}{*}{ 2004-2007 } & $C$ & $0.050501 * *$ & 0.023538 & 2.145542 & 0.0319 \\
\hline & MON & -0.085218 & 0.059733 & -1.426652 & 0.1537 \\
\hline \multirow{2}{*}{ 2005-2008 } & C & 0.007328 & 0.022817 & 0.321154 & 0.7481 \\
\hline & MON & -0.049337 & 0.056780 & -0.868912 & 0.3849 \\
\hline \multirow{2}{*}{ 2006-2009 } & C & 0.003101 & 0.024124 & 0.128533 & 0.8977 \\
\hline & MON & -0.074223 & 0.059191 & -1.253965 & 0.2099 \\
\hline \multirow{2}{*}{ 2007-2010 } & C & -0.010509 & 0.026849 & -0.391412 & 0.6955 \\
\hline & MON & -0.075768 & 0.060438 & -1.253649 & 0.2100 \\
\hline \multirow{2}{*}{ 2008-2011 } & C & -0.037319 & 0.026646 & -1.400546 & 0.1613 \\
\hline & MON & $-0.115311^{* *}$ & 0.058631 & -1.966723 & 0.0492 \\
\hline \multirow{2}{*}{ 2009-2012 } & C & 0.027955 & 0.025222 & 1.108357 & 0.2677 \\
\hline & MON & $-0.152362 * * *$ & 0.057206 & -2.663376 & 0.0077 \\
\hline \multirow{2}{*}{ 2010-2013 } & C & $0.055642 * * *$ & 0.023326 & 2.385381 & 0.0171 \\
\hline & MON & $-0.125147^{* *}$ & 0.054371 & -2.301702 & 0.0214 \\
\hline \multirow{2}{*}{ 2011-2014 } & C & $0.043240 * *$ & 0.022821 & 1.894701 & 0.0581 \\
\hline & MON & $-0.103073^{* *}$ & 0.054172 & -1.902687 & 0.0571 \\
\hline \multirow{2}{*}{ 2012-2015 } & C & 0.022602 & 0.024391 & 0.926628 & 0.3541 \\
\hline & MON & -0.031182 & 0.054416 & -0.573028 & 0.5666 \\
\hline \multirow{2}{*}{ 2013-2016 } & C & -0.003396 & 0.024662 & -0.137685 & 0.8905 \\
\hline & MON & -0.054570 & 0.055156 & -0.989369 & 0.3225 \\
\hline \multirow{2}{*}{ 2014-2017 } & C & -0.003645 & 0.025147 & -0.144964 & 0.8847 \\
\hline & MON & -0.077123 & 0.054443 & -1.416585 & 0.1566 \\
\hline
\end{tabular}


Table 2 (cont.). Results of time-varying day-of-the-week effect

\begin{tabular}{|c|c|c|c|c|c|}
\hline Sample period & Variables & Coefficient & Std. error & Z-statistic & Prob. \\
\hline \multirow{2}{*}{ 2000-2003 } & C & $0.057454^{* * *}$ & 0.023125 & 2.484520 & 0.0130 \\
\hline & TUE & 0.019680 & 0.050843 & 0.387066 & 0.6987 \\
\hline \multirow{2}{*}{ 2001-2004 } & C & 0.041404 & 0.026750 & 1.547837 & 0.1217 \\
\hline & TUE & 0.022305 & 0.057744 & 0.386276 & 0.6993 \\
\hline \multirow{2}{*}{ 2002-2005 } & C & 0.029192 & 0.027916 & 1.045713 & 0.2957 \\
\hline & TUE & 0.002863 & 0.057628 & 0.049684 & 0.9604 \\
\hline \multirow{2}{*}{ 2003-2006 } & C & 0.023061 & 0.025906 & 0.890171 & 0.3734 \\
\hline & TUE & 0.040443 & 0.053729 & 0.752724 & 0.4516 \\
\hline \multirow{2}{*}{ 2004-2007 } & C & $0.041490^{*}$ & 0.024766 & 1.675323 & 0.0939 \\
\hline & TUE & -0.041838 & 0.050211 & -0.833252 & 0.4047 \\
\hline \multirow[b]{2}{*}{ 2005-2008 } & C & 0.005400 & 0.023544 & 0.229341 & 0.8186 \\
\hline & TUE & -0.042134 & 0.049461 & -0.851869 & 0.3943 \\
\hline \multirow[b]{2}{*}{ 2006-2009 } & C & 0.006912 & 0.024469 & 0.282465 & 0.7776 \\
\hline & TUE & $-0.091559 *$ & 0.053431 & -1.713589 & 0.0866 \\
\hline \multirow{2}{*}{ 2007-2010 } & C & 0.000322 & 0.026537 & 0.012117 & 0.9903 \\
\hline & TUE & $-0.126228^{* *}$ & 0.058935 & -2.141828 & 0.0322 \\
\hline \multirow{2}{*}{ 2008-2011 } & C & -0.040365 & 0.026058 & -1.549030 & 0.1214 \\
\hline & TUE & -0.094021 & 0.059299 & -1.585554 & 0.1128 \\
\hline \multirow{2}{*}{ 2009-2012 } & C & 0.020807 & 0.025267 & 0.823498 & 0.4102 \\
\hline & TUE & $-0.109241^{* *}$ & 0.055645 & -1.963180 & 0.0496 \\
\hline \multirow{2}{*}{ 2010-2013 } & C & $0.042412 *$ & 0.023605 & 1.796725 & 0.0724 \\
\hline & TUE & -0.057357 & 0.052198 & -1.098842 & 0.2718 \\
\hline & C & 0.035686 & 0.023421 & 1.523699 & 0.1276 \\
\hline 2011-2014 & TUE & -0.069239 & 0.050757 & -1.364110 & 0.1725 \\
\hline & C & 0.028978 & 0.024647 & 1.175702 & 0.2397 \\
\hline $2012-2015$ & TUE & -0.069504 & 0.052117 & -1.333627 & 0.1823 \\
\hline & C & -0.000182 & 0.024755 & -0.007333 & 0.9941 \\
\hline 2013-2016 & TUE & -0.076240 & 0.053406 & -1.427543 & 0.1534 \\
\hline & C & 0.007015 & 0.025457 & 0.275555 & 0.7829 \\
\hline 2014-2017 & TUE & $-0.139265 * * *$ & 0.052201 & -2.667848 & 0.0076 \\
\hline Sample period & Variables & Coefficient & Std. error & Z-statistic & Prob. \\
\hline & C & $0.072296^{* * *}$ & 0.022511 & 3.211537 & 0.0013 \\
\hline $2000-2003$ & WED & -0.056800 & 0.050143 & -1.132762 & 0.2573 \\
\hline & C & $0.048232 *$ & 0.026357 & 1.829966 & 0.0673 \\
\hline 2001-2004 & WED & -0.011938 & 0.056927 & -0.209710 & 0.8339 \\
\hline & C & 0.028742 & 0.027305 & 1.052626 & 0.2925 \\
\hline $2002-2005$ & WED & 0.004899 & 0.060876 & 0.080481 & 0.9359 \\
\hline & C & 0.032853 & 0.025578 & 1.284393 & 0.1990 \\
\hline 2003-2006 & WED & -0.008554 & 0.057337 & -0.149189 & 0.8814 \\
\hline & C & 0.035719 & 0.024371 & 1.465644 & 0.1427 \\
\hline 2004-2007 & WED & -0.009343 & 0.054376 & -0.171820 & 0.8636 \\
\hline & C & -0.000662 & 0.023091 & -0.028676 & 0.9771 \\
\hline 2005-2008 & WED & -0.009801 & 0.052488 & -0.186738 & 0.8519 \\
\hline & C & -0.009740 & 0.024193 & -0.402610 & 0.6872 \\
\hline 2006-2009 & WED & -0.010035 & 0.054041 & -0.185686 & 0.8527 \\
\hline & C & -0.043041 & 0.026583 & -1.619117 & 0.1054 \\
\hline $2007-2010$ & WED & 0.085125 & 0.057294 & 1.485751 & 0.1373 \\
\hline & C & $-0.079282^{* * *}$ & 0.026627 & -2.977442 & 0.0029 \\
\hline 2008-2011 & WED & $0.096647^{*}$ & 0.056722 & 1.703854 & 0.0884 \\
\hline & C & -0.022121 & 0.025683 & -0.861325 & 0.3891 \\
\hline 2009-2012 & WED & $0.103621 * *$ & 0.053848 & 1.924331 & 0.0543 \\
\hline & C & 0.013000 & 0.024227 & 0.536593 & 0.5915 \\
\hline 2010-2013 & WED & $0.093631^{*}$ & 0.050238 & 1.863764 & 0.0624 \\
\hline & C & 0.007731 & 0.023489 & 0.329108 & 0.7421 \\
\hline 2011-2014 & WED & 0.074442 & 0.050373 & 1.477792 & 0.1395 \\
\hline & C & 0.012091 & 0.024373 & 0.496108 & 0.6198 \\
\hline $2012-2015$ & WED & 0.020999 & 0.052594 & 0.399264 & 0.6897 \\
\hline & C & -0.014915 & 0.024689 & -0.604124 & 0.5458 \\
\hline 2013-2016 & WED & 0.003612 & 0.054364 & 0.066433 & 0.9470 \\
\hline & C & -0.024049 & 0.024616 & -0.976977 & 0.3286 \\
\hline 2014-2017 & WED & 0.027704 & 0.056368 & 0.491477 & 0.6231 \\
\hline Full sample & Variables & Coefficient & Std. error & Z-statistic & Prob. \\
\hline & C & $0.050023^{* *}$ & 0.023290 & 2.147810 & 0.0317 \\
\hline $2000-2003$ & THUR & 0.055886 & 0.049180 & 1.136355 & 0.2558 \\
\hline & C & 0.045330 & 0.029419 & 1.540848 & 0.1234 \\
\hline $2001-2004$ & THUR & -0.008415 & 0.066497 & -0.126542 & 0.8993 \\
\hline & C & 0.008963 & 0.027664 & 0.323987 & 0.7459 \\
\hline 2002-2005 & THUR & $0.101029^{*}$ & 0.058846 & 1.716828 & 0.0860 \\
\hline & C & 0.018242 & 0.026238 & 0.695246 & 0.4869 \\
\hline 2003-2006 & THUR & 0.062713 & 0.053538 & 1.171379 & 0.2414 \\
\hline
\end{tabular}


Table 2 (cont.). Results of time-varying day-of-the-week effect

\begin{tabular}{|c|c|c|c|c|c|}
\hline Sample period & Variables & Coefficient & Std. error & Z-statistic & Prob. \\
\hline \multirow{2}{*}{ 2004-2007 } & $C$ & 0.023586 & 0.025054 & 0.941424 & 0.3465 \\
\hline & THUR & 0.049382 & 0.049897 & 0.989678 & 0.3223 \\
\hline \multirow{2}{*}{ 2005-2008 } & C & -0.004557 & 0.023725 & -0.192065 & 0.8477 \\
\hline & THUR & 0.009136 & 0.049529 & 0.184464 & 0.8536 \\
\hline \multirow{2}{*}{ 2006-2009 } & C & -0.011204 & 0.024758 & -0.452523 & 0.6509 \\
\hline & THUR & -0.003552 & 0.054183 & -0.065549 & 0.9477 \\
\hline \multirow{2}{*}{ 2007-2010 } & C & -0.016329 & 0.026544 & -0.615166 & 0.5384 \\
\hline & THUR & -0.045622 & 0.061356 & -0.743552 & 0.4571 \\
\hline \multirow{2}{*}{ 2008-2011 } & C & $-0.061112 * *$ & 0.026506 & -2.305548 & 0.0211 \\
\hline & THUR & 0.006549 & 0.059199 & 0.110627 & 0.9119 \\
\hline \multirow{2}{*}{ 2009-2012 } & C & -0.013169 & 0.025563 & -0.515145 & 0.6065 \\
\hline & THUR & 0.060724 & 0.056813 & 1.068835 & 0.2851 \\
\hline \multirow{2}{*}{ 2010-2013 } & C & 0.025459 & 0.024029 & 1.059528 & 0.2894 \\
\hline & THUR & 0.027523 & 0.052140 & 0.527859 & 0.5976 \\
\hline \multirow{2}{*}{ 2011-2014 } & $C$ & 0.024402 & 0.023633 & 1.032540 & 0.3018 \\
\hline & THUR & -0.007803 & 0.050917 & -0.153255 & 0.8782 \\
\hline \multirow{2}{*}{ 2012-2015 } & C & 0.019471 & 0.024361 & 0.799280 & 0.4241 \\
\hline & THUR & -0.014930 & 0.054977 & -0.271572 & 0.7860 \\
\hline \multirow{2}{*}{ 2013-2016 } & C & -0.017121 & 0.024846 & -0.689084 & 0.4908 \\
\hline & THUR & 0.013653 & 0.054756 & 0.249340 & 0.8031 \\
\hline \multirow{2}{*}{ 2014-2017 } & C & -0.028589 & 0.024949 & -1.145909 & 0.2518 \\
\hline & THUR & 0.048462 & 0.054654 & 0.886711 & 0.3752 \\
\hline Sample period & Variables & Coefficient & Std. error & Z-statistic & Prob. \\
\hline \multirow{2}{*}{ 2000-2003 } & $C$ & $0.062326^{* * *}$ & 0.023010 & 2.708615 & 0.0068 \\
\hline & $\mathrm{FRI}$ & -0.004218 & 0.051177 & -0.082413 & 0.9343 \\
\hline \multirow{2}{*}{ 2001-2004 } & C & $0.046259 *$ & 0.026192 & 1.766183 & 0.0774 \\
\hline & $\mathrm{FRI}$ & -0.001692 & 0.060755 & -0.027842 & 0.9778 \\
\hline \multirow{2}{*}{ 2002-2005 } & C & 0.030701 & 0.027085 & 1.133498 & 0.2570 \\
\hline & $\mathrm{FRI}$ & -0.004770 & 0.062970 & -0.075747 & 0.9396 \\
\hline \multirow{2}{*}{$2003-2006$} & $C$ & 0.027363 & 0.025643 & 1.067093 & 0.2859 \\
\hline & $\mathrm{FRI}$ & 0.023235 & 0.056294 & 0.412746 & 0.6798 \\
\hline \multirow{2}{*}{ 2004-2007 } & C & 0.014991 & 0.024785 & 0.604853 & 0.5453 \\
\hline & $\mathrm{FRI}$ & $0.103494 * *$ & 0.050950 & 2.031278 & 0.0422 \\
\hline \multirow{2}{*}{ 2005-2008 } & $C$ & -0.022456 & 0.023863 & -0.941045 & 0.3467 \\
\hline & $\mathrm{FRI}$ & $0.104585 * *$ & 0.049239 & 2.124005 & 0.0337 \\
\hline \multirow{2}{*}{ 2006-2009 } & C & $-0.048674 * *$ & 0.024878 & -1.956504 & 0.0504 \\
\hline & $\mathrm{FRI}$ & $0.198700^{* * *}$ & 0.050898 & 3.903892 & 0.0001 \\
\hline \multirow{2}{*}{ 2007-2010 } & C & $-0.059103^{* *}$ & 0.026889 & -2.198000 & 0.0279 \\
\hline & $\mathrm{FRI}$ & $0.183823^{* * *}$ & 0.057249 & 3.210959 & 0.0013 \\
\hline & C & $-0.081739 * * *$ & 0.026491 & -3.085510 & 0.0020 \\
\hline 2008-2011 & $\mathrm{FRI}$ & $0.113986 * *$ & 0.057799 & 1.972098 & 0.0486 \\
\hline & C & -0.020927 & 0.025359 & -0.825218 & 0.4092 \\
\hline 2009-2012 & FRI & $0.099735^{*}$ & 0.057909 & 1.722258 & 0.0850 \\
\hline & $C$ & 0.019498 & 0.023765 & 0.820426 & 0.4120 \\
\hline $2010-2013$ & $\mathrm{FRI}$ & 0.057325 & 0.054249 & 1.056696 & 0.2907 \\
\hline & C & 0.004044 & 0.023295 & 0.173578 & 0.8622 \\
\hline 2011-2014 & FRI & $0.093649^{*}$ & 0.052541 & 1.782376 & 0.0747 \\
\hline & C & 0.000406 & 0.024182 & 0.016791 & 0.9866 \\
\hline $2012-2015$ & FRI & 0.079664 & 0.057007 & 1.397435 & 0.1623 \\
\hline & C & -0.033845 & 0.024595 & -1.376082 & 0.1688 \\
\hline 2013-2016 & $\mathrm{FRI}$ & $0.099453^{*}$ & 0.056523 & 1.759511 & 0.0785 \\
\hline & C & $-0.043603^{*}$ & 0.024720 & -1.763910 & 0.0777 \\
\hline 2014-2017 & $\mathrm{FRI}$ & $0.123159^{* *}$ & 0.057368 & 2.146825 & 0.0318 \\
\hline
\end{tabular}

Note: significance of estimated coefficients is taken at prob. $<5 \%$. *,**, *** correspond to $10,5,1 \%$.

effects. This shows that the significant negative MON effect shown in Table 1 is not persistent at all time. It means that only five of the estimated 15 sub-periods are associated with significant negative MON effect. From the results of the TUE effect, the full sample results show significant negative TUE. Looking at the sub-periods, there are positive TUE effect sub-periods and others when the TUE effect is negative. This conforms to the time varying behavior. Specifically, only four windows in 2006-2009, 2007-2010, 2009-2012, and 2014-2017 have significant a negative TUE effect.

In terms of the signs of the return's coefficients, WED and THUR returns vary over time between positive and negative coefficients. As with the full sample results, the results of sub-periods analyses on WED and THUR effect does not show any observable anomalies. For all the fifteen win- 
dows, there is no trace of WED and THUR effect except for one window of positive WED effect in 2009-2012. The last day-of-the-week effect result is presented for FRI effect. This effect is found in full sample (Table 1). In overlapping the sub-period analyses, it is clear that positive FRI is not found at all times. In fact, there are two sub-periods of negative FRI effect in the first three sub-periods, though they are not statistically significant. Basically, there are nine (9) sub-periods of statistically significant (some at 10\%) FRI effects out of fif- teen (15) total sub-periods. It implies that the FRI effect fluctuates over time according to $\mathrm{AMH}$.

Overall, while the full sample reveals that the MON, TUE and FRI effect exist, the overlapping sub-period estimations show that they only exist in some and not all sub-periods, hence, time-varying and adaptive. For better understanding of the time-varying behavior, this study presents the coefficients of MON, TUE and FRI effect in Figure 1. The bluish line indicates the coefficient, while the reddish

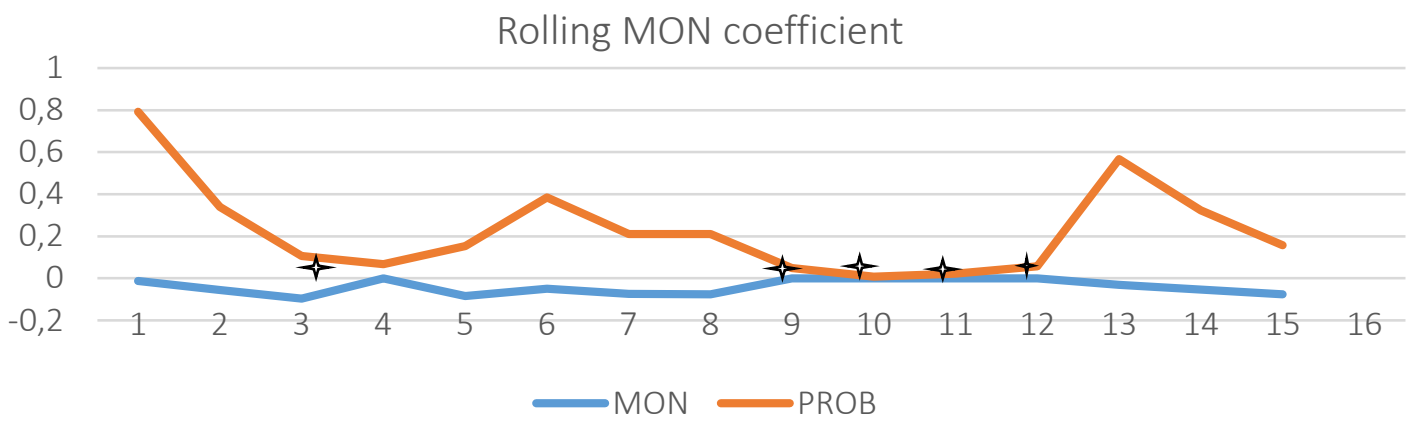

a)

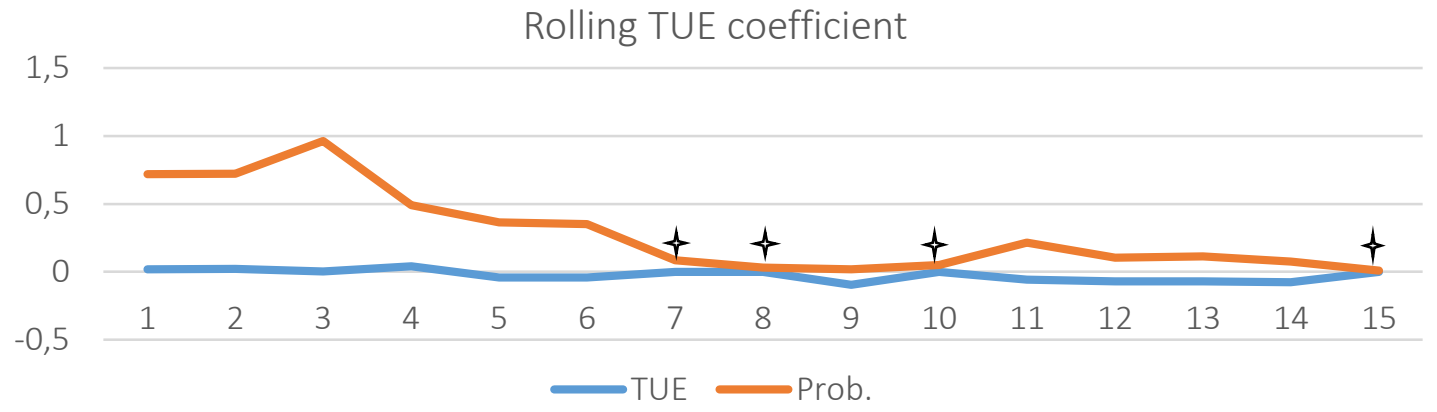

b)

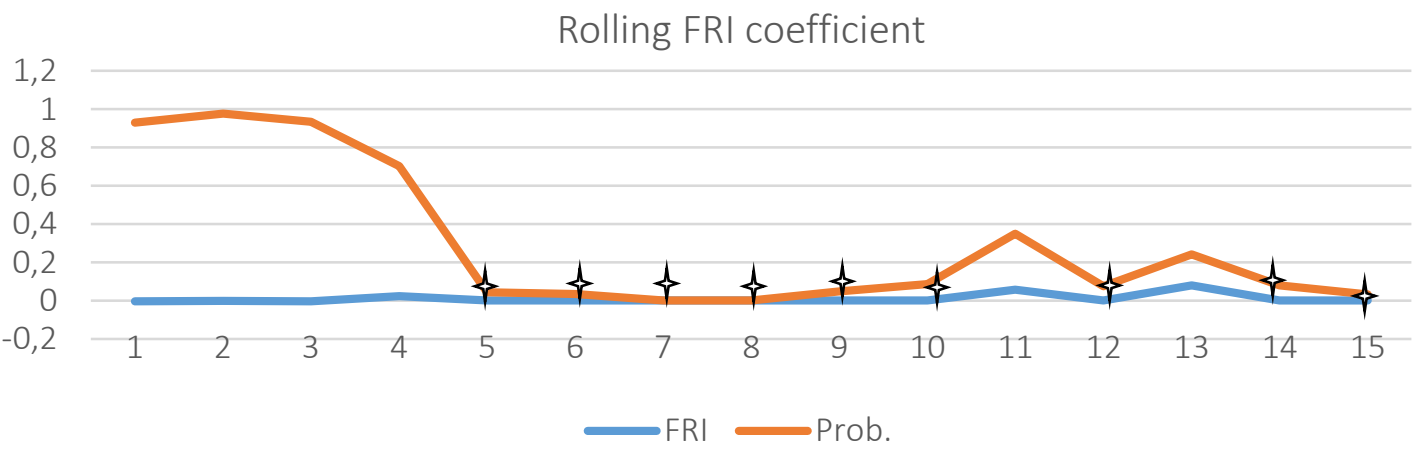

c)

Figure 1. Time-varying day-of-the-week effect 
line stands for the $p$-values. It can be seen from the figure that significant MON effect is only found in $4^{\text {th }}, 9^{\text {th }}, 10^{\text {th }}, 11^{\text {th }}$, and $12^{\text {th }}$ sub-periods, while other periods are not associated with significant MON effect. Similarly, Figure 1 shows that significant negative TUE effect is found in $7^{\text {th }}, 8^{\text {th }}, 10^{\text {th }}$, and $15^{\text {th }}$ sub-sample. Lastly, positive FRI effect is associated with $5^{\text {th }}, 6^{\text {th }}, 7^{\text {th }}, 8^{\text {th }}, 9^{\text {th }}, 10^{\text {th }}, 12^{\text {th }}, 14^{\text {th }}$, and $15^{\text {th }}$.

\subsection{Calendar effect and market condition results}

Since the previous section reveals that MON, TUE, and FRI effects behave in a changing version, hence, adaptive. This study also examines under which market conditions these recognized calendar effects can be found. After separating the data into a positive and negative (months) condition, the study then estimates the behavior of the calendar effects during each condition using the previously described GARCH $(1,1)$ regression model. The study has the data separated into Up and Down months similar to Fabozzi and Francis (1977) and Urquhart and McGroarty (2014) by identifying the months with positive return as Up condition and months with negative return as Down period.

Results of the estimation of calendar anomalies under Bull and Bear condition are presented in Table 3. The results show that the MON effect is more obvious during Bull market than Bear market even though the coefficients are negative during both. In other words, the MON is more negative and statistically significant during Bull months but not statistically significant during Bear months. This implies that the time-varying MON effect established in the previous subsection is due to changing Bull and Bear market condition. Another effect that is time varying is the TUE effect. Table shows that the changing behavior is a result of changing market condition as the TUE coefficient is insignificant in Bull periods and became statistically significant in Bear periods. The results further show that Wednesday effect is not existing and not affected by market condition with insignificant coefficient.

Surprisingly, the THUR effect, which was not found in full sample and sub-periods appear under Bear periods. Table 3 shows that THUR coefficient changes from insignificant negative in Bull to significant positive in Bear. Moreover, the establishment of time-variation in FRI effect in previous section can now be traced to market condition that changes. The positive Friday effect is found in both Bull and Bear periods, but the effect is higher in Bear (0.068197) as compared to Bull, relative to other days (C). Thus, the three (MON, TUE, FRI)

Table 3. Results of day-of-the-week in Up and Down condition

\begin{tabular}{|c|c|c|c|c|c|c|c|c|c|}
\hline Condition & Variables & Coefficient & Std. error & Z-statistic & Prob. & Q-stat & Prob* & ARCH & Prob* \\
\hline \multirow{2}{*}{ Bull } & C & $0.147571^{* * *}$ & 0.015744 & 9.373316 & 0.0000 & 1.9519 & 0.162 & 0.002114 & 0.9633 \\
\hline & MON & $-0.086709 * * *$ & 0.034705 & -2.498461 & 0.0125 & & & & \\
\hline \multirow{2}{*}{ Bear } & C & $-0.118583^{* * *}$ & 0.017773 & -6.672113 & 0.0000 & 1.0915 & 0.296 & 0.554621 & 0.4565 \\
\hline & MON & -0.051019 & 0.038516 & -1.324625 & 0.1853 & & & & \\
\hline \multirow{2}{*}{ Bull } & C & $0.133713^{* * *}$ & 0.016122 & 8.293959 & 0.0000 & 2.0168 & 0.156 & 0.001938 & 0.9649 \\
\hline & TUE & -0.013619 & 0.033269 & -0.409368 & 0.6823 & & & & \\
\hline \multirow{2}{*}{ Bear } & C & $-0.104888^{* * *}$ & 0.017707 & -5.923694 & 0.0000 & 1.0847 & 0.298 & 0.527373 & 0.4678 \\
\hline & TUE & $-0.121203^{* * *}$ & 0.036201 & -3.348062 & 0.0008 & & & & \\
\hline \multirow{2}{*}{ Bull } & C & $0.121237 * * *$ & 0.015932 & 7.609877 & 0.0000 & 1.9844 & 0.159 & 0.002874 & 0.9573 \\
\hline & WED & 0.046864 & 0.033192 & 1.411939 & 0.1580 & & & & \\
\hline \multirow{2}{*}{ Bear } & C & $-0.128065^{* * *}$ & 0.017341 & -7.385171 & 0.0000 & 1.2979 & 0.255 & 0.539289 & 0.4628 \\
\hline & WED & -0.003310 & 0.038683 & -0.085565 & 0.9318 & & & & \\
\hline \multirow{2}{*}{ Bull } & C & $0.132963 * * *$ & 0.016307 & 8.153775 & 0.0000 & 1.9947 & 0.158 & 0.002427 & 0.9607 \\
\hline & THUR & -0.009985 & 0.033199 & -0.300756 & 0.7636 & & & & \\
\hline \multirow{2}{*}{ Bear } & C & $-0.149308^{* * *}$ & 0.017368 & -8.596743 & 0.0000 & 0.8734 & 0.350 & 0.503714 & 0.4780 \\
\hline & THUR & $0.108466 * * *$ & 0.036870 & 2.941870 & 0.0033 & & & & \\
\hline \multirow{2}{*}{ Bull } & C & $0.118298 * * *$ & 0.016135 & 7.331932 & 0.0000 & 2.1359 & 0.144 & 0.003117 & 0.9555 \\
\hline & $\mathrm{FRI}$ & $0.063927 * *$ & 0.033531 & 1.906528 & 0.0566 & & & & \\
\hline \multirow{2}{*}{ Bear } & C & $-0.142728^{* * *}$ & 0.017585 & -8.116332 & 0.0000 & 1.2955 & 0.255 & 0.491058 & 0.4835 \\
\hline & FRI & $0.068197 * *$ & 0.038980 & 1.749523 & 0.0502 & & & & \\
\hline
\end{tabular}

Note: significance of estimated coefficients is taken at prob. $<5 \%{ }^{*}, * *, * * *$ correspond to $10,5,1 \%$. 
day-of-the-week effects found in the full sample, found to be time-varying in subsample, are affected by market condition. However, the Thursday effect is also found in Bear condition. On the whole, MON and THUR effects are found in Bull, while TUE and FRI are found in Bear.

\section{DISCUSSION AND IMPLICATIONS}

The study examines whether day-of-the-week effect conforms to AMH in the Nigerian stock market. Based on the examination of the day-ofthe-week effect in absolute form, the study finds that there are negative MON and TUE effects, as well as the positive FRI effect in the Nigerian stock market. These effects translate to what is theoretically referred to as the weekend effect characterized by positive and significantly high FRI returns and negative and significantly low MON returns. These findings are associated with investors' mood in behavioral finance. People are believed to have low mood or be pessimistic on Monday being first day of the week, while they have high mood or optimism on Friday due to weekend break. This translates to what is often referred to as TGIF (Thank God It's Friday) in Nigeria.

The presence of significant negative Monday returns and positive Friday returns as posited by weekend effect of calendar anomalies is statistically significant. This is consistent with the a priori expectation, which violated the capital market theory. The finding is consistent with Siami Namini, Rahnama Roudposhti, and Janani (2013) in Terah where major findings from the return equations of GARCH (1,1), GARCH-M, and Modified GARCH $(1,1)$ models showed that weekend effect occurs during the first and second half of the month and
Osazevbaru and Oboreh (2014) in Nigeria who established the present of this effect in Nigeria using regression and GARCH. The findings violate Brishan (2012) who reported that there is no weekend effect in South Africa. In any case, the implication is that investors can beat the market by buying on Monday for sales on Friday. The negativity of Tuesday also implies that investors can buy during the day for sales on Friday in order to earn returns.

This study also evaluates how calendar anomalies vary (behave) over time in the Nigerian stock market, since the latest trend is to examine time-varying anomaly, all the identified anomalies are also examined bit by bit. This study found that MON, TUE and FRI effects are the only day-of-the-week adaptive effects. Timevarying Monday effect aligns with Urquhart and McGroarty (2014) who found the same in the US. This study found that Tuesday and Friday are time-varying. This supports research by Obalade and Muzindutsi (2019) who found that day-ofthe-week effect depends on market condition in the African stock market.

Lastly, the study analyzes how calendar anomalies respond to changing regimes or market conditions in the Nigerian stock markets. Generally, the day-of-the-week effects, especially the negative MON and TUE effects, as well as the positive FRI effect is time varying due to changing Bull and Bear market condition. Specifically, Monday effect is associated with Up condition. This finding contradicts Urquhart and McGroarty (2014) who held that Monday effect is significant in Bear, Down and crashes. It is recommended that investors should not be dogmatic in the exploitation of the identified calendar effects since the effect is time-varying.

\section{CONCLUSION}

This study aims at evaluating the presence of day-of-the-week effect and determining the relevance of $\mathrm{AMH}$ in describing the behavior of the identified calendar effect. To achieve the objectives, the study evaluates the calendar effect in full sample and overlapping sub-periods. Based on the test of hypotheses and the findings of the study, the study concludes that there is a significant weekend effect evidenced by significant negative Monday effect and significant positive Friday effect. Secondly, there is evidence of stock market calendar anomaly in the Nigerian stock returns and violation of efficient market. Thirdly, the mentioned anomaly is not present every time as previous studies have suggested. Finally, some 
of the daily anomalies are present in Bull periods, while some are present in Bear periods. In Nigeria, just few papers are examining AMH. The current study contributes to literature by showing that dayof-the-week effect depends on time and that Up and Down conditions affect the calendar effect in the Nigerian stock market. In general, AMH seems to be a more realistic theory when it comes to the behavior of stock market returns and calendar anomalies. Therefore, stakeholders must consider possibility of adaptive behavior while interacting with the stock market. Investors must be careful to take time variation into consideration; otherwise, they may incur a loss by believing that day-of-the-week effect is unvarying. Going forward, other anomalies such as holiday and monthly effect can also be examined using AMH approach. Future researchers can investigate AMH in other markets such as Nigerian foreign exchange and oil markets.

\section{REFERENCES}

1. Ajao, M. G., \& Wemambu, M. U. (2012). Volatility Estimation and Stock Price Prediction in the Nigerian Stock Market. International Journal of Financial Research, 3(1), 1-14. https://doi. org/10.5430/ijfr.v3n1p2

2. Akkaya, G. C., \& Çimen, A. (2013). Calendar Anomalies at Borsa Istanbul. International Journal of Economics And Finance Studies, 5(1), 141-148. Retrieved from http://www.sobiad.org/ejournals/ journal_IJEF/archieves/2013_1/G. Cenk-akkaya.pdf

3. Alagidede, P. (2013). Month of the Year and Pre-Holiday Effects in African Stock Markets. Sajems, 16(1), 64-74. https://doi. org/10.4102/sajems.v16i1.246

4. Borges, M. R. (2009). Calendar effects in stock markets: Critique of previous methodologies and recent evidence in European countries (Working Paper WP37/2009/DE/ UECE). School of Economics and Management, Technical University of Lisbon, Portugal. Retrieved from https://core.ac.uk/download/ pdf/6851482.pdf

5. Brishan, R. (2012). Calendar Effects on the Nine Economic Sectors of the Johannesburg Stock Exchange (Master thesis). School of Economic and Business Sciences, University of the Witwatersrand, Johannesburg.

6. Fabozzi, F. J., \& Francis, J. C. (1977). Stability Tests for Alphas and Betas Over Bull and Bear Market Conditions. The Journal of Finance, 32(4), 10931099.
7. Efayena, O. (2014). Monthly Stock Market Seasonality: The Nigerian Evidence. Research Journal of Finance and Accounting, 5(9), 22-35. Retrieved from https://www.iiste. org/Journals/index.php/RJFA/article/view/13033/13420

8. Güler, S., \& Çimen, A. (2014). Day of the Month Effect in Emerging Markets. Journal of Yasar University, 9(33), 5636-5648. Retrieved from https://journal.yasar.edu. tr/wp-content/uploads/2014/01/ Vol9_No33_4_S.-G\%C3\%BClerA.-G\%C3\%BCl\%C3\%A7imen.pdf

9. Gulseven, O. (2014).

Multidimensional Analysis of Monthly Stock Market Returns. Scientific Annals of the Alexandru Ioan Cuza University of Iaşi Economic Sciences, 61(2), 181196. https://doi.org/10.2478/aicue-2014-0013

10. Kampman, T. (2012). Behavioral finance: The January effect (Bachelor Thesis). Finance Tilburg University. Retrieved from http:// arno.uvt.nl/show.cgi?fid=129529

11. Kroon, M. (2008). Seasonal Anomalies in the Swedish Stock Market from an Industry Perspective (Master Thesis). Department of Economics, Lund University, Sweden. Retrieved from https://pdfs.semanticscholar. org/ffcd/baab212e4c0768cbff0918b0aae8d4465294.pdf

12. Lo, A. W. (2004). The adaptive markets hypothesis: market efficiency from an evolutionary perspective. Journal of Portfolio Management, 30(5), 15-29. Retrieved from https://papers.ssrn. com/sol3/papers.cfm?abstract id $=602222$

13. Obalade, A. A., \& Muzindutsi, P-F. (2018). Are there Cycles of Efficiency and Inefficiency: Adaptive Market Hypothesis in Three African Stock Markets. Frontiers in Finance and Economics, 15(1), 185-202. Retrieved from https://www.researchgate.net/ publication/331833939

14. Obalade, A. A., \& Muzindutsi, P-F. (2019). Calendar Anomalies, Market Regimes, and the Adaptive Market Hypothesis in African Stock Markets. Central European Management Journal, 27(4), 71-94. https://doi.org/10.7206/ cemj.2658-0845.10

15. Olowe, R. A. (2011). Exchange Rate Volatility, Global Financial Crisis and the Day-of-the-Week Effect. KCA Journal of Business Management, 3(3), 30-43. Retrieved from https://doi.org/10.4314/kjbm. v3i3.72101

16. Osarumwense, O.-I. (2015). Dayof-the-week effect in the Nigerian Stock Market Returns and Volatility: Does the Distributional Assumptions Influence Disappearance? European Financial and Accounting Journal, 10(4), 33-44. https://doi. org/10.18267/j.efaj.148

17. Osarumwense, O.-I. (2016). Day-of-the-week Anomaly: An Illusion or Reality? Evidence From Naira/Exchange Rate. CBN Journal of Applied Statistics, 7(1), 311-332. Retrieved from https:// www.researchgate.net/publication/306602755 
18. Osazevbaru, H. O., \& Oboreh, J. (2014). The "Monday Effect" in Nigerian Stock Market: Evidence and Implication. Journal of Social Sciences and Public Policy, 6(1), 1-8.

19. Patel, J. B. (2016). The January Effect Anomaly Reexamined In Stock Returns. The Journal of Applied Business Research, 32(1), 317-324. https://doi.org/10.19030/ jabr.v32i1.9540

20. Siami Namini, R., Rahnama Roudposhti, F., \& Janani, M. H. (2013). A Study to Examine TimeVarying Effectiveness of Stock Returns on Tehran Stock Exchange. International Journal of Financial Research, 4(2), 154-161. https://doi. org/10.5430/ijfr.v4n2p154.
21. Tan, R. S. K., \& Tat, W. L. (1998). The diminishing calendar anomalies in the stock exchange of Singapore. Applied Financial Economics, 8(2), 119-125. https:// doi.org/10.1080/096031098333096

22. Tevdovski, D., Mihajlov, M., \& Sazdovski, I. (2012). The Day of the Week Effect in South Eastern Europe Stock Markets. Annals of the "Constantin Brâncuşi” University of Târgu Jiu, Economy Series, 3, 20-24.

23. Urquhart, A., \& McGroarty, F. (2014). Calendar effects, market conditions and the Adaptive Market Hypothesis: Evidence from long-run U.S. data.
International Review of Financial Analysis, 35, 154-166. https://doi. org/10.1016/j.irfa.2014.08.003

24. WingKeung, W., Aman, A., \& NeeTat, W. (2006). The Disappearing Calendar Anomalies in the Singapore Stock Market. Lahore Journal of Economics, 11(2), 123-139.

25. Yousop, N. L. B. M., Sipon, Z., \& Yoke, C. S. K. (2014). Lunar Effect: Analysis on Emerging Countries Stock Returns, Prior and During Financial Crisis. Journal of Emerging Economies and Islamic Research, 2(2), 1-15. Retrieved from https://pdfs.semanticscholar. org/4301/744a0balf665d5142c3ef 74d413e966d6eab.pdf 